\title{
Identification of duck, partridge, pheasant, quail, chicken and turkey meats by species-specific PCR assays to assess the authenticity of traditional game meat Alheira sausages
}

\author{
Joana S. Amaral a, b, *, Cristina G. Santos a, b, Vitor S. Melo ${ }^{\text {a, b }}$, Joana Costa ${ }^{\text {, }}$ \\ M. Beatriz P.P. Oliveira ${ }^{a}$, Isabel Mafra ${ }^{a}{ }^{*}$ \\ ${ }^{a}$ REQUIMTE, Departamento de Ciências Químicas, Faculdade de Farmácia, Universidade do Porto, Rua de Jorge Viterbo Ferreira, 228, 4050-313 Porto, \\ Portugal \\ b Instituto Politécnico de Bragança, Campus de Sta. Apolónia, 5301-857 Bragança, Portugal
}

\section{A R T I C L E I N F O}

\section{Article history:}

Received 10 April 2014

Received in revised form

6 June 2014

Accepted 3 July 2014

Available online 10 July 2014

\section{Keywords:}

Alheira

Game meat

Species identification

Authenticity

PCR

Meat products

\begin{abstract}
A B S T R A C T
Game meat Alheira (Alheira de caça) sausage is a traditional fermented product typical from the Northeast region of Portugal, having bread and meats (including game) as main ingredients. It is a particularly appreciated product by consumers that commands higher prices, especially in comparison with the common Alheira produced with pork and poultry meats. Following our previous work in which several mammalian game meat species were successfully identified in game meat Alheira sausages for authentication purposes, the present work aimed at identifying game bird's species for the overall assessment of labelling compliance. For that purpose, several species-specific PCR assays targeting mitochondrial DNA for the detection of game and domestic bird's meat, namely duck, partridge, pheasant, quail, chicken and turkey were developed, optimised and applied to commercial samples of game meat Alheira for their authentication. The assays revealed a high specificity and sensitivity to detect the addition of all evaluated species down to a level of $0.01 \%(w / w)$. PCR results indicated the existence of several inconsistencies with the labelled information, namely the absence of declared game species (duck, partridge and pheasant) and the presence of undeclared poultry meat, pointing out to adulterations owing to substitution of game by domestic meat species. Since this is considered a high-valued traditional product that should be valorised and protected, this work puts in evidence the need for inspection programs to enforce regulation.
\end{abstract}

() 2014 Elsevier Ltd. All rights reserved.

\section{Introduction}

Alheira is a highly appreciated type of sausage that contains meat, bread and other ingredients, being traditionally smoked and naturally-fermented. Its production is a long-established practice in the Northeast of Portugal that goes back to the fifteenth century during the Inquisition period. At that time, the Jewish population created a type of sausage identical in appearance to those eaten by the Christians living in the region, but having chicken and other bird's meat replacing the pork meat. Along the years, Alheira sausages turned out to be much appreciated and the recipe became

\footnotetext{
* Corresponding authors. REQUIMTE, Departamento de Ciências Químicas, Faculdade de Farmácia, Universidade do Porto, Rua de Jorge Viterbo Ferreira, 228, 4050-313 Porto, Portugal. Tel.: +351 220428640.

E-mail addresses: jamaral@ipb.pt (J.S. Amaral), isabel.mafra@ff.up.pt (I. Mafra).
}

popular among the local population. Nowadays, this traditional Portuguese sausage is produced mainly with a combination of pork and poultry meats, pork lard, regional wheat bread and olive oil mixed with salt, garlic and spices. Besides the regular Alheira, other kinds are currently available in the market, among which game meat Alheira (Alheira de caça) is considered one of the most attractive and sought products. Similar to other game meat products, game meat Alheira is generally perceived by consumers as being healthier, tastier and having higher quality than the common Alheira. For this reason, there has been an increasing trend for its consumption during the last years, in spite of the relatively high price. Since game meat Alheira generally commands higher prices than the common product and game meats used for its production can be, in some cases, restricted to hunting seasons and animal availability, it is a product very prone to fraudulent meat substitutions (Amaral, Santos, Melo, Oliveira, \& Mafra, 2014). Therefore, to authenticate this type of processed meat product and 
contribute to avoid unfair competition among producers, providing accurate information to consumers, there is a need to develop efficient methodologies to assess meat species identification and verify the compliance with labelling (Amaral et al., 2014; Ballin, Vogensen, \& Karlsson, 2009; Fajardo et al., 2010).

Several techniques, mainly relying on protein and DNA analysis, have been proposed so far for the identification of meat species in complex mixtures. Protein-based methods, including highperformance liquid chromatography, electrophoretic techniques and enzyme-linked immunosorbent assays, are generally well suited and give satisfactory results with respect to species identification in raw meats (Asensio, González, García, \& Martín, 2008; Ballin, 2010). Nevertheless, they can be significantly less sensitive and present limitations when applied to thermally processed foods due to protein denaturation and alterations of specific epitopes (Rodríguez, García, González, Hernández, \& Martín, 2005). In recent works, DNA has been chosen as target molecules for species identification purposes in processed products owing to their higher stability when compared to proteins (Ghovvati, Nassiri, Mirhoseini, Moussavi, \& Javadmanesh, 2009; Mafra, Ferreira, \& Oliveira, 2008; Rojas et al., 2010; Soares, Amaral, Mafra, \& Oliveira, 2010). Moreover, DNA analysis coupled with polymerase chain reaction (PCR) presents a fast, sensitive and highly specific alternative to proteinbased methods, enabling the identification of species of origin even in complex processed foods (Amaral et al., 2014; Bottero \& Dalmasso, 2011; Mafra et al., 2008; Soares et al., 2010). In a previous work, several species-specific PCR assays were optimised and successfully applied for the identification of different mammalian game (deer, hare and wild rabbit) and domestic (pork and cow) animals in commercial game meat Alheiras. In the referred work, the use of specific primers targeting short DNA fragments proved to be a powerful tool to discriminate meat species in the particular case of Alheira, a fermented sausage with a complex composition (Amaral et al., 2014). In the present work, we report the optimisation of different species-specific PCR assays for the identification of game (partridge, pheasant, quail and wild duck) and domestic (chicken and turkey) bird's meat to assess the authenticity of game meat Alheiras. The assays were applied to several samples of commercial game meat Alheiras to verify labelling compliance and evaluate the possible existence of fraudulent practices.

\section{Materials and methods}

\subsection{Samples and binary model mixtures}

Samples of pork (Sus scrofa), chicken (Gallus gallus), and turkey (Meleagris gallopavo) were acquired from the retail market. Samples of authentic game meats, namely partridge (Alectoris spp.), red legged partridge (Alectoris rufa), pheasant (Phasianus colchinus), wild duck (Anas platyrhynchos) and quail (Coturnix coturnix) were acquired from local hunters. The samples consisted of entire animals (with feathers and non-eviscerated) to confirm their authenticity. For each bird species, binary reference mixtures containing known proportions of the considered meat $(0.01 \%, 0.1 \%$, $0.5 \%, 1 \%, 2.5 \%, 5 \%, 10 \%$ and $20 \%(\mathrm{w} / \mathrm{w}))$ in pork meat were prepared to a final weight of $100 \mathrm{~g}$.

A total of 18 different commercial samples of game meat Alheira sausages acquired in the retail market, in local markets and directly from local artisanal producers were evaluated in the present study. All samples, including authentic meats, binary model mixtures and commercial Alheira sausages were separately minced in a blender, using different material and different blender containers previously treated with DNA decontaminator solution to avoid contaminations (DNA-ExitusPlus' ${ }^{\mathrm{TM}}$, ApplChem, Darmstad, Germany).
A wide range of non-target animal species was included in the study for specificity assays, namely cow (Bos taurus), hare (Lepus spp.), red deer (Cervus elaphus), wild rabbit (Oryctolagus cuniculus), wild boar (S. scrofa scrofa), ostrich (Struthio camelus), sheep (Ovis aries) and goat (Capra hircus). Other ingredients, which can be used in the production of Alheira sausages, were included in the study for specificity assays, namely wheat bread, rye bread, corn, soybean, garlic, parsley, paprika, onions, white pepper, laurel and chilli.

The binary meat mixtures and samples were immediately stored at $-20{ }^{\circ} \mathrm{C}$ after preparation until DNA extraction.

\subsection{DNA extraction}

DNA was extracted using the Wizard method with minor modifications as described by Soares et al. (2010). The extractions were performed in duplicate assays for each binary mixture and sample.

\subsection{DNA quantification and purity}

The quality of extracted DNA was analysed by electrophoresis in a $1.0 \%$ agarose gel containing Gel Red $1 \times$ (Biotium, Hayward, CA, USA) for staining and carried out in TAE buffer $\left(40 \mathrm{mmol} \mathrm{L}^{-1}\right.$ Tris-acetate, $1 \mathrm{mmol} \mathrm{L}^{-1}$ EDTA) for $40 \mathrm{~min}$ at $120 \mathrm{~V}$. The agarose gel was visualised under UV light and a digital image was obtained using a Kodak Digital Science ${ }^{\mathrm{TM}}$ DC120 (Rochester, NY, USA).

The DNA was quantified by spectrophotometry using a Shimadzu UV-1800 spectrophotometer (Shimadzu Corporation, Kyoto, Japan). The DNA concentration was determined by UV absorbance at $260 \mathrm{~nm}$ ( 1 absorbance unit corresponds to $50 \mu \mathrm{g} \mathrm{mL}^{-1}$ of $d s \mathrm{DNA}$ ). The purity of extracts was determined by the ratio of the absorbance at 260 and $280 \mathrm{~nm}$.

\subsection{Target gene selection and oligonucleotide primers}

The species-specific oligonucleotide primers used in this work targeted mitochondrial genes of pheasant, partridge and quail, previously reported in the literature (Table 1 ). For the identification of meat from duck, chicken and turkey, new primers were designed on the basis of the mitochondrial cytb gene sequence from various animal species available in the NCBI (Nacional Center for Biotechnology Information) Genbank database. The specific primers were designed using the software Primer3 Output designing tool (http:// frodo.wi.mit.edu/primer3/). The nucleotide sequences were submitted to a basic local alignment search tool BLAST (http://blast. ncbi.nlm.nih.gov/Blast.cgi), which identifies regions of local similarity among homologue sequences of different species and calculates the statistical significance of the matches. Primer specificity was assessed using the Primer-BLAST tool that allows revealing homologies in relation to all sequences available in the database (Genbank). Primer properties and the absence of hairpins and selfhybridization were assessed using the software Oligo calc (http:// www.basic.northwestern.edu./biotools/oligocalc.html).

The framents obtained with the Chk-F/Chk-R, Tuk-F/Tuk-R and Duk-f/Duk-R primers (Table 1) were sequenced to confirm their identity. PCR products were purified in Cut\&Spin DNA gel extraction columns (GRISP Research Solutions, Porto, Portugal) to remove interfering components. The purified products were sent to a specialised research facility (STABVIDA, Lisbon, Portugal) for sequencing. The method of choice for small PCR fragments was the direct sequencing of both strands in opposite directions, allowing the production of two complementary sequences with good quality.

To assess amplifiability of DNA extracts, universal primers targeting a conserved 18S rRNA gene fragment in all eukaryotic cells 
Table 1

Oligonucleotide primers.

\begin{tabular}{|c|c|c|c|c|c|}
\hline Species & Primer & Target gene & Sequence $\left(5^{\prime} \rightarrow 3^{\prime}\right)$ & Amplicon (bp) & Reference \\
\hline \multirow[t]{2}{*}{ Anas platyrhynchos } & Duk-F & $c y t b$ & CTC CGT CCT AAT CCT ATT CCT GG & 111 & This work ${ }^{\mathrm{a}}$ \\
\hline & Duk-R & & GAG GAG GTT GGC CAC TAG TGT & & \\
\hline \multirow[t]{2}{*}{ Alectoris spp. } & 12SALEC-F & 12S rRNA & CGA CCT AAA AAC CAT CTT AGT TCC CA & 141 & Rojas et al. (2009) \\
\hline & 12SALEC-R & & CGT AGT TCT CGG GCG GAT ATA TTG & & \\
\hline \multirow[t]{2}{*}{ Phasianus colchicus } & 12SPHA-F & 12S rRNA & AGT GGT CAT ATG TTA TCC TCA CC & 113 & Rojas et al. (2009) \\
\hline & 12SPHA-R & & GGG GTA AAA TTA GTC GTG GAG & & \\
\hline \multirow[t]{2}{*}{ Coturnix coturnix } & 12SCOT-F & 12S rRNA & GAT TTA GCA GTA AAA TGG GAT CAC TTT & 129 & Rojas et al. (2009) \\
\hline & 12SCOT-R & & TCG TCT TTG GCT TAA TGG TTG G & & \\
\hline \multirow[t]{2}{*}{ Gallus gallus } & Chk-F & $c y t b$ & TCG CCC TCA CAA TCC TTA CAA CGA & 118 & This work ${ }^{\mathrm{b}}$ \\
\hline & Chk-R & & CTG GGA GGT CGA TTA GGG AGT TG & & \\
\hline \multirow[t]{2}{*}{ Meleagris gallopavo } & Tuk-F & $c y t b$ & CCC TTC GTA ATC GCA GGA ATT AC & 109 & This work ${ }^{c}$ \\
\hline & Tuk-R & & GGT GGA ATG GGA TTT TGT CAG C & & \\
\hline \multirow[t]{2}{*}{ Eukaryotic } & 18SEU-F & 18S rRNA & TCT GCC CTA TCA ACT TTC GAT GG & 140 & Fajardo et al. (2008) \\
\hline & 18SEU-R & & TAA TTT GCG CGC CTG CTG & & \\
\hline
\end{tabular}

\footnotetext{
a Genbank accession number NC_009684.

b Genbank accession number NC_001323.

c Genbank accession number AY157979.
}

were used (Table 1). The primers were synthesised by Eurofins MWG Operon (Ebersberg, Germany).

\subsection{Species-specific PCR amplification}

The PCR assays were performed in a total reaction volume of $25 \mu \mathrm{L}$ containing $2 \mu \mathrm{L}$ of DNA extract ( $20 \mathrm{ng}$ for meats and $100 \mathrm{ng}$ for samples and other tested food ingredients), buffer $\left(67 \mathrm{mmol} \mathrm{L}^{-1}\right.$ Tris- $\mathrm{HCl}$ ( $\mathrm{pH} 8.8$ ), $16 \mathrm{mmol} \mathrm{L}^{-1}\left(\mathrm{NH}_{4}\right)_{2} \mathrm{SO}_{4}, 0.01 \%$ Tween 20 ), $0.2 \mathrm{mmol} \mathrm{L}^{-1}$ of each dNTP (Bioron, Ludwigshafen, Germany), $400 \mathrm{nmol} \mathrm{L}^{-1}$ of each primer for the target species or $600 \mathrm{nmol} \mathrm{L}^{-1}$ for eukaryotic sequences (Table 1), $1.5 \mathrm{mmol} \mathrm{L}^{-1}$ of $\mathrm{MgCl}_{2}$ for duck, pheasant and eukaryotic genes and $2.0 \mathrm{mmol} \mathrm{L}^{-1}$ for the others, and $1 \mathrm{U}$ of SuperHot Taq DNA polymerase (Genaxxon Bioscience $\mathrm{GmbH}$, Ulm, Germany). The reactions were performed in a thermal cycler MJ Mini (Bio-Rad Laboratories, Hercules, CA, USA) using the programs described in Table 2. The amplified fragments were analysed by electrophoresis in a $2.0 \%$ agarose gel, using similar conditions as described above for genomic DNA analysis. Each extract was amplified at least in duplicate assays.

\section{Results and discussion}

\subsection{Specificity and sensitivity of the species-specific PCR assays}

In this work, the specific identification of chicken, turkey and duck was based on the design of new species-specific primers (Table 1). Considering that Alheira sausages are fermented and thermally treated products, their extracted DNA can, consequently, present a high level of degradation. Therefore, the primers were designed for small target DNA sequences of the mitochondrial cytb gene. In such cases, it is particularly advised to use sequences from mitochondrial DNA (mtDNA), which are several fold more abundant than those of nuclear genome, as well as to detect short sequences in order to increase the possibility of amplifying fragmented DNA (Girish et al., 2005). The great knowledge on animal mtDNA gene organisation, together with the large availability of reported sequences in many species, makes it possible to easily design species-specific primers for amplification. Moreover, the intraspecific variability of mtDNA offers the possibility of breed discrimination (Montiel-Sosa et al., 2000).

For each species, the in silico analysis confirmed the specificity of the designed primers for the selected sequences with $100 \%$ identity. In the cases of chicken, turkey and duck, sequencing confirmed the expected fragments. To further assess the specificity of the designed new primers for chicken, turkey and duck, as well as for the other tested species, each set of primers (Table 1) was assayed by PCR amplification against other animal species commonly used as food, including game and domestic animal meats (DNA extracts from pork, wild boar, hare, rabbit, red deer, cow, ostrich, goat and sheep meats) and ingredients generally used in the manufacture of Alheira (DNA extracts from wheat bread, rye bread, garlic, parsley, paprika, onion, white pepper, laurel, chilli, corn and soybean). The obtained results showed that each pair of primers was only able to produce the expected fragments when the corresponding DNA for which they were designed was present, demonstrating their specificity (data not shown). Universal primers (18SEU-F/18SEU-R) targeting the nuclear 18S rRNA gene for eukaryotic DNA were used to confirm the presence of amplifiable DNA in the extracts. Positive amplifications were obtained for all the tested extracts when submitted to PCR amplification using the referred universal primers.

For each species under evaluation, model binary mixtures were prepared containing known amounts of duck, partridge, pheasant, quail, chicken or turkey meat in pork meat. For each species, the DNA extracts obtained from these mixtures were then used for

Table 2

Temperature programs used in PCR amplification with different primers.

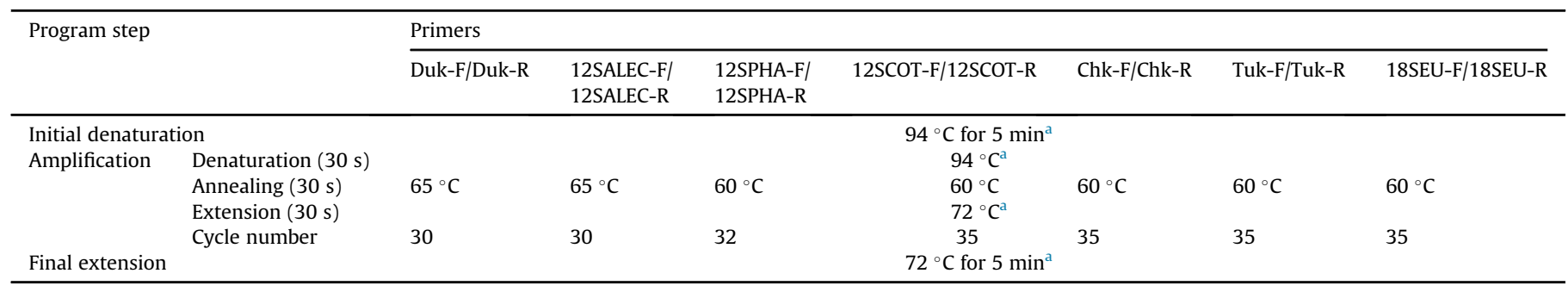

\footnotetext{
a These conditions were the same for all sets of primers.
} 
method optimisation regarding the PCR amplification conditions. The optimised assays allowed achieving a sensitivity of $0.01 \%$ for all the evaluated species (Fig. 1).

\subsection{Application of species-specific PCR assays to game meat Alheira samples}

Several samples of commercial game meat Alheira were submitted to DNA extraction using the modified Wizard method. As previously reported (Amaral et al., 2014), adequate purity and yield were obtained, though the values were lower compared to the ones obtained for the model binary mixtures. The optimised PCR conditions for each species under evaluation (Fig. 1) were then applied to the sample extracts for meat species identification and
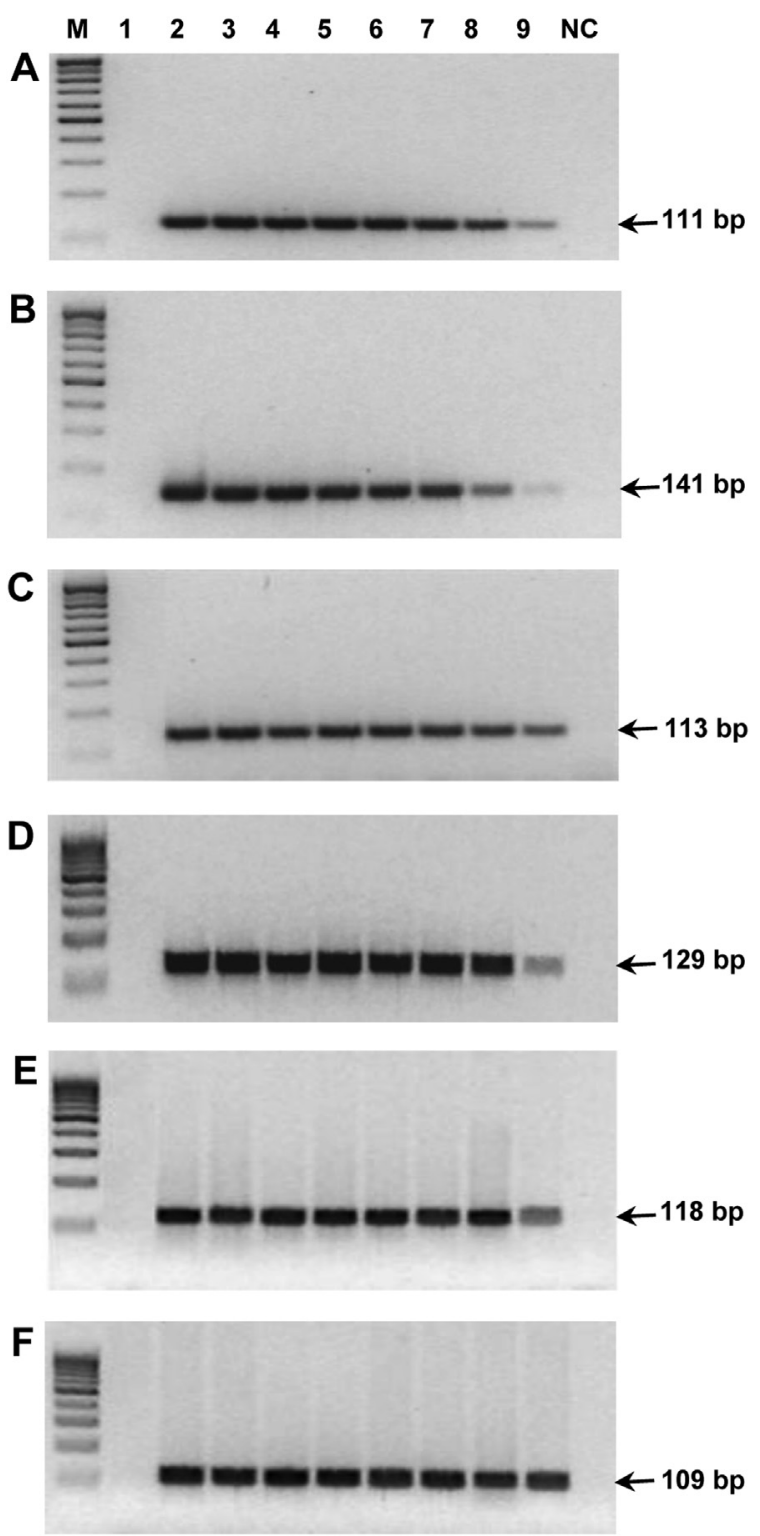

Fig. 1. Agarose gel electrophoresis of PCR products of binary reference mixtures of duck meat targeting cytb gene (A), partridge meat targeting 12S rRNA gene (B), pheasant meat targeting 12S rRNA gene (C), quail meat targeting 12S rRNA gene (D), chicken meat targeting cytb gene (E) and turkey meat targeting cytb gene (F), in pork meat. Legend: M, 100 bp DNA ladder (Bioron, Ludwigshafen, Germany); NC, negative control; Lane 1, pork; Lanes $2-9,20 \%, 10 \%, 5 \%, 2.5 \%, 1 \%, 0.5 \%, 0.1 \%, 0.01 \%$ of each target meat in pork meat. verification of labelling compliance (Fig. 2, and Table 3). As observed in Table 3, four of the eighteen samples, namely those acquired as game meat Alheira from small artisanal producers, did not specify the meat species used in their preparation (samples 8,9 , 11 and 12). Additionally, sample 6 did not specify the origin of game meat species included as ingredient, simply declaring that it contained $10 \%$ of game meat in its composition. The remaining thirteen samples listed all the ingredients on the label. From the eight game meat Alheira that declared the presence of duck/wild duck, five were positive for this species (Fig. 2A, Table 3), while samples 13-15 gave negative results, suggesting incorrect label regarding this species. In what concerns partridge meat, five samples declared it as an ingredient, however partridge DNA was only detected in sample 4, evidencing the occurrence of misleading information in samples 1, 3, 14 and 15 (Fig. 2B, Table 3). Pheasant DNA was not detected in any of the samples, although two (2 and 3) were labelled as containing pheasant meat (Fig. 2C, Table 3). Regarding quail species-specific PCR assay, all samples gave negative results, which was an expected result for the thirteen labelled samples as none of them declared quail meat in the list of ingredient (Fig. 2D, Table 3). In the five cases of Alheira sold as containing game meat (samples 6, 8, 9, 11 and 12), besides the absence of quail, the samples were also negative for all the other tested game bird species. The same was previously obtained for the presence of different mammalian game meats in the referred five samples (Amaral et al., 2014), with the exception for sample 12 that effectively had one game meat species (red deer) in its composition, justifying the label of game meat product.

In addition to the detection of game bird's meat, in this work the presence of chicken and turkey was also tested. These two species are considered as the most consumed and world-wide produced bird meats, being generally less expensive than game meat and, consequently, likely to be used for the fraudulent substitution of game bird's meat. From the thirteen samples that specified the meat species used in their production, three declared the presence of chicken, one declared turkey and four poultry meat as ingredients (Table 3 ). The results of the PCR assays evidenced the presence of chicken DNA in seven samples, beyond those labelled as containing chicken or poultry meats, which clearly suggests the fraudulent substitution of game meat by chicken meat (Fig. 2E, Table 3). In relation to turkey meat, only one sample declared it (sample 4), whose presence was effectively detected. Turkey was also identified in other three samples that did not mention its

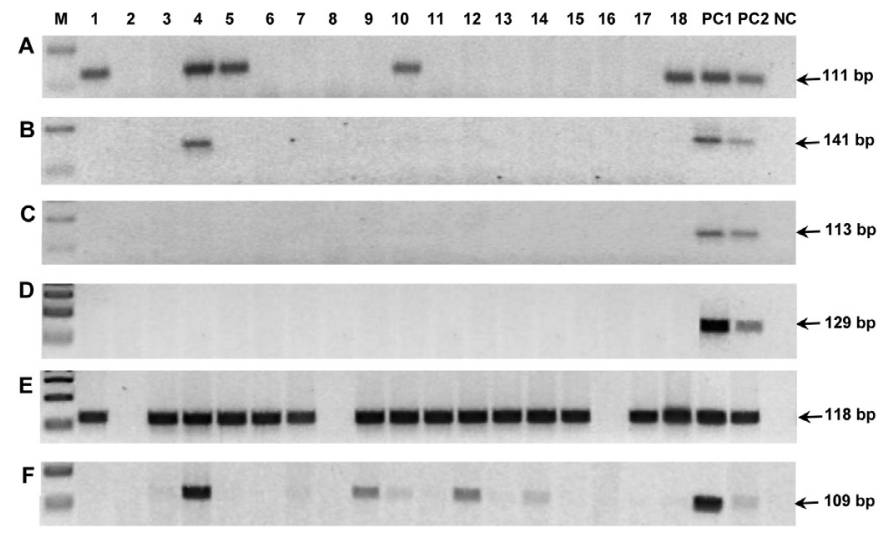

Fig. 2. Agarose gel electrophoresis of PCR products of commercial samples of game meat Alheiras targeting cytb gene of duck (A), 12S rRNA gene of partridge (B), 12S rRNA gene of pheasant (C), cytb gene of turkey (D), and cytb gene of chicken (E). M, $100 \mathrm{bp}$ DNA ladder (Bioron, Ludwigshafen, Germany); Lanes 1-18, commercial samples of game meat Alheiras, Lanes PC1 and PC2, positive controls, corresponding to $1 \%$ and $0.1 \%$, respectively, of each targeted species; NC, negative control. 
Table 3

Summarised results of species-specific PCR to assess compliance with labelling of samples of game meat Alheiras.

\begin{tabular}{|c|c|c|c|c|c|c|c|c|c|c|c|c|}
\hline \multirow[t]{2}{*}{ Sample } & \multicolumn{2}{|l|}{ Duck } & \multicolumn{2}{|c|}{ Partridge } & \multicolumn{2}{|c|}{ Pheasant } & \multicolumn{2}{|l|}{ Quail } & \multicolumn{2}{|c|}{ Chicken } & \multicolumn{2}{|c|}{ Turkey } \\
\hline & Label & PCR & Label & PCR & Label & PCR & Label & PCR & Label & PCR & Label & PCR \\
\hline 1 & $\mathrm{X}^{\mathrm{a}}$ & + & $X$ & - & & - & & - & & + & & - \\
\hline 2 & & - & & - & $X$ & - & & - & & - & & - \\
\hline 3 & & - & $X$ & - & $X$ & - & & - & & + & & - \\
\hline 4 & $X$ & + & $X$ & + & & - & & - & $X$ & + & $X$ & + \\
\hline 5 & $X$ & + & & - & & - & & - & $X$ & + & & - \\
\hline 6 & $\mathrm{G}^{\mathrm{b}}$ & - & G & - & $\mathrm{G}$ & - & G & - & $\mathrm{P}^{\mathrm{c}}$ & + & $\mathrm{P}$ & - \\
\hline 7 & & - & & - & & - & & - & & + & & - \\
\hline 8 & G & - & G & - & G & - & $G$ & - & & - & & - \\
\hline 9 & $G$ & - & G & - & $\mathrm{G}$ & - & G & - & & + & & + \\
\hline 10 & $X$ & + & & - & & - & & - & $\mathrm{P}$ & + & $\mathrm{P}$ & + \\
\hline 11 & G & - & G & - & $\mathrm{G}$ & - & G & - & & + & & - \\
\hline 12 & G & - & $G$ & - & $\mathrm{G}$ & - & G & - & & + & & + \\
\hline 13 & $X$ & - & & - & & - & & - & $X$ & + & & - \\
\hline 14 & $X$ & - & $\mathrm{X}$ & - & & - & & - & & + & & + \\
\hline 15 & $X$ & - & $X$ & - & & - & & - & & + & & - \\
\hline 16 & & - & & - & & - & & - & & - & & - \\
\hline 17 & & - & & - & & - & & - & $\mathrm{P}$ & + & $\mathrm{P}$ & - \\
\hline 18 & $X$ & + & & - & & - & & - & $\mathrm{P}$ & + & $\mathrm{P}$ & - \\
\hline
\end{tabular}

a $\mathrm{X}$, labelled species.

b G, acquired as game meat Alheira/labelled as containing game meat without specifying meat species.

c $\mathrm{P}$, labelled as containing poultry meat.

presence (Fig. 2F, Table 3), namely in sample 14 and in two samples sold as artisanal Alheiras (samples 9 and 12). From the four samples labelled as containing poultry, all contained chicken meat, while turkey was detected in only one of them (Table 3 ). Regarding the overall results of bird species detection, it can be noted several inconsistencies with labelling, namely the absence of declared game meats and the presence of undeclared poultry meat.

The global analysis of labelling compliance of all the tested game and common meat species (Table 4) suggests the fraudulent exclusion of a great number of game meats, which were replaced by the undeclared addition of poultry and bovine meats. From the five samples that were sold as game meat Alheira, only one game species was identified in one sample, namely red deer. As highlighted in the identification of mammal species (Amaral et al., 2014), sample 4 was in complete compliance with the labelled bird species.

\section{Conclusions}

This work aimed at assessing the authenticity of game meat Alheiras regarding the presence of game bird's meat. For that purpose, species-specific PCR assays were successfully developed and optimised, at a limit of detection of $0.01 \%$ for the meat species under evaluation (duck, partridge, pheasant, quail, chicken and

Table 4

Global results of identification of species in game meat Alheiras in the present work and previous report (Amaral et al., 2014).

\begin{tabular}{lcc}
\hline $\begin{array}{l}\text { Declared } \\
\text { information/ingredients }\end{array}$ & $\begin{array}{l}\mathrm{N}^{\circ} \text { of labelled } \\
\text { samples }\end{array}$ & $\begin{array}{l}\mathrm{N}^{\circ} \text { of positive } \\
\text { PCR results }\end{array}$ \\
\hline Rabbit & 9 & 2 \\
Hare & 1 & 0 \\
Red deer & 7 & 6 \\
Cow & 1 & 12 \\
Pork & 14 & 18 \\
Duck & 8 & 5 \\
Partridge & 5 & 1 \\
Pheasant & 2 & 0 \\
Quail & 0 & 0 \\
Poultry & 7 & 15 \\
Game & 5 & 1 \\
\hline
\end{tabular}

turkey). The proposed methodologies, which proved to be highly specific and sensitive, were then effectively applied for the evaluation of eighteen commercial samples of game meat Alheiras, a Portuguese traditional sausage. Several samples showed the existence of irregularities, mainly due to the absence of declared game species (partridge, pheasant and quail) and the presence of undeclared poultry species, mainly chicken. The obtained results seem to indicate a high incidence of adulteration due to substitution of game birds with poultry in at least $44 \%$ of samples. The global analysis, considering also the previous report (Amaral et al., 2014), suggests the substitution of game by bovine meat species in $61 \%$ of the samples and the complete compliance with labelling in only one sample.

This work puts in evidence the importance of control and inspection programs as well as the need to verify labelling statements. Considering the recent fraud scandals in the meat industry and that processed meat products are susceptible targets for adulteration, there is a need for increased transparency in the sector. In particular, special attention should be given to traditional processed meat products, such as Alheira sausages, in order to contribute for their valorisation and protection. Therefore, the proposed technique can be a suitable and valuable tool to address the referred authenticity issues.

\section{Acknowledgements}

The authors acknowledge the financial support of the University of Porto/Santander Totta "Projectos pluridisciplinares 2010" and the Fundação para a Ciência e a Tecnologia (FCT) through grant no. PEst-C/EQB/LA0006/2013.

\section{References}

Amaral, J. S., Santos, C. G., Melo, V. S., Oliveira, M. B. P. P., \& Mafra, I. (2014) Authentication of a traditional game meat Alheira by species-specific PCR assays to detect hare, rabbit, red deer, pork and cow meats. Food Research International, $60,140-145$.

Asensio, L., González, I., García, T., \& Martín, R. (2008). Determination of food authenticity by enzyme-linked immunosorbent assay (ELISA). Food Control, 19, 1-8.

Ballin, N. Z. (2010). Authentication of meat and meat products. Meat Science, 86, $577-587$.

Ballin, N. Z., Vogensen, F. K., \& Karlsson, A. H. (2009). Species determination - can we detect and quantify meat adulteration? Meat Science, 83, 165-174. 
Bottero, M. T., \& Dalmasso, A. (2011). Animal species identification in food products: evolution of biomolecular methods. The Veterinary Journal, 190, 34-38.

Fajardo, V., González, I., Martín, I., Rojas, M., García, T., \& Martín, R. (2010). A review of current PCR-based methodologies for the authentication of meats from game animal species. Trends in Food Science and Technology, 21, 408-421.

Fajardo, V., González, I., Martín, I., Rojas, M., Hernández, P., García, T., et al. (2008). Real-time PCR for detection and quantification of red deer (Cervus elaphus), fallow deer (Dama dama), and roe deer (Capreolus capreolus) in meat mixtures. Meat Science, 79, 289-298.

Ghovvati, S., Nassiri, M. R., Mirhoseini, S. Z., Moussavi, A. H., \& Javadmanesh, A. (2009). Fraud identification in industrial meat products by multiplex PCR assay Food Control, 20, 696-699.

Girish, P. S., Anjaneyulu, A. S. R., Viswas, K. N., Shivakumar, B. M., Anand, M., Patel, M., et al. (2005). Meat species identification by polymerase chain reaction-restriction fragment length polymorphism (PCR-RFLP) of mitochondrial 12S rRNA gene. Meat Science, 70, 107-112.

Mafra, I., Ferreira, I. M. P. L. V. O., \& Oliveira, M. B. P. P. (2008). Food authentication by PCR-based methods. European Food Research and Technology, 227, 649-665.
Montiel-Sosa, J. F., Ruiz-Pesini, E., Montoya, J., Roncalés, P., López-Pérez, M. J., \& Pérez-Martos, A. (2000). Direct and highly species-specific detection of pork meat and fat in meat products by PCR amplification of mitochondrial DNA. Journal of Agricultural and Food Chemistry, 48, 2829-2832.

Rodríguez, M. A., García, T., González, I., Hernández, P. E., \& Martín, R. (2005) TaqMan real-time PCR for the detection and quantification of pork in meat mixtures. Meat Science, 70, 113-120.

Rojas, M., González, I., Fajardo, V., Martín, I., Hernández, P. E., García, T., et al. (2009). Authentication of meats from quail (Coturnix coturnix), pheasant (Phasianus colchicus), partridge (Alectoris spp.), and guinea fowl (Numida meleagris) using polymerase chain reaction targeting specific sequences from the mitochondrial 12S rRNA gene. Food Control, 20, 896-902.

Rojas, M. González, I. Pavón, M. A., Pegels, N., Lago, A, Hernández, P. E, et al (2010). Novel TaqMan real-time polymerase chain reaction assay for verifying the authenticity of meat and commercial meat products from game birds. Food Additives \& Contaminants: Part A, 27, 749-763.

Soares, S., Amaral, J. S., Mafra, I., \& Oliveira, M. B. P. P. (2010). Quantitative detection of pork's meat by duplex PCR. Meat Science, 85, 531-536. 